Advances in Social Science, Education and Humanities Research (ASSEHR), volume 81

1st International Conference on Social and Political Development (ICOSOP 2016)

\title{
Quality of Life of Pregnant Women in the Dimensions of Physical Health Aspects, Psychological well-being, Social Relations and Environment in Medan, North Sumatera Province
}

\author{
Siti Saidah Nasution
}

\author{
Department of Maternity and Pediatric Nursing, Faculty of Nursing \\ University of North Sumatera \\ saidah.nasution@yahoo.com
}

\begin{abstract}
The quality of life of pregnant women suffering from HIV-AIDS infection is very much affected by physical health aspects, psychological well-being, social relations and environmental life in the surrounding societies. This study aimed at analyzing the quality of life of HIV-AIDS-infected pregnant women in Medan, North Sumatera. The research design was comparative descriptive methodology with 64 pregnant women recruited as samples, comprising of 32 HIV-AIDS-infected pregnant women and the other 32 HIV-AIDS-negative pregnant women. The data were taken by proposing respondents to answer demographic questionnaires and questionnaires regarding quality of life that had been modified to relate to pregnancy referring to questionnaires designed by WHO namely WHOQOL- BREF. The data were analysed by testing independent t-test. The research on quality of life of pregnant women on the four dimensions resulted that the quality of life of HIV-AIDS-positive pregnant women on the dimension of physical health aspect is $81.2 \%$ moderate and $15.6 \%$ poor; on the dimension of psychological health $78.1 \%$ moderate and $9.4 \%$ poor; on the dimension of social relation $87.5 \%$ moderate and $12.5 \%$ poor; and on the dimension of environmental support $78.3 \%$ moderate and $9.4 \%$ poor. Then the quality of life of HIV-AIDS-negative pregnant women on the dimension of physical health is $65.6 \%$ moderate; on the psychological well-being $53.1 \%$ moderate; on the dimension of social relation $68.8 \%$ moderate and $12.5 \%$ poor; on the dimension of environmental support $84.4 \%$ moderate and no poor quality found on this dimension. There is a difference between those qualities of life of HIV-AIDS-positive pregnant women and HIV-AIDS-negative pregnant women by $p=0.000$. In general conclusion, the quality of life of pregnant women infected by HIV-AIDS is worse than that of HIV-AIDS-negative pregnant women. Thus it is needed that health care providers, family members and societies maximize their helping those HIVAIDS-positive pregnant women in adapting to physical and psychological state to improve their quality of life on each dimension.
\end{abstract}

Keywords: Quality of Life, Pregnant Women

\section{INTRODUCTION}

Pregnant women who are being infected by HIV-AIDS are at high risk of maintaining reproductive health which needs acquisition and adaptation to changes in both them and in their families. These changes affect the quality of life of those individuals. The quality of life stresses the importance of someone's subjective perceptions on performing their own functional roles and comparing them to the internal, standard roles which they possess to embody something which is more idealistic and goes with what is to be achieved. Based on the concept developed by WHOQL-BREF, quality of life can be measured by examining aspects namely physical health, psychological well-being, social relations and environmental relations, as in Power in Lopez and Snyder, 2004 (Noftri, 2009). The risks of undergoing complications and anxiety of passing the infection to the babies which are being conceived can negatively affect the physical and psychological well-being of pregnant mothers. The complications referred to are ruptured perineum, defect baby birth, low birth weight, premature baby, and possible transmission of HIV to baby (Reeder et al., 2013). Psychological changes occurred are for example, ambivalence, doubt about her 
pregnancy, depression, excessive worry about the baby, and even postpartum blues after delivery. According to a research conducted by Kotze in South Africa, pregnant women suffered from HIV infection experience the increasing depression and anxiety of societal stigma. In term of social health, the HIV-AIDS patients face various social problems such as stigmatization, discrimination, environmental and social isolation.

International Centre for Research on Women (2003) cites that there are many forms of stigmatization, among them are nicknaming/ designating, pointing, scape goating, quipping, laughing, labelling, blaming, shaming, judging, slandering, suspecting, ignoring, rejecting, isolating, not sharing things with people with HIV-AIDS, avoiding, staying away, disturbing, physically abusing, and torturing. According to surveys on the people with some degree of HIV-AIDS stigma, stigma and discrimination cause very bad psychological effect so that feeling guilty and ashamed and having desire to commit suicide emerge as a negative effect of the stigma and discrimination (World Report, 2013). For HIVAIDS infected pregnant mothers, delivery will become a fear especially regarding the possibility of transmitting the infection to others especially to the babies being conceived. In view of this, health care providers are called to conduct indeed studies on how the quality of life of pregnant women and its understanding relates to the treatment of pregnancy and the delivery by HIV-AIDS infected pregnant women.

Acquired Immunodeficiency Syndrome (AIDS) is a collective symptom as to diminishing ability to survive because of the infection of HIV in someone's body. This infection causes the patients to halt their immune system function and then the body will easily acquire various diseases. During pregnancy, the immune system function is forced to work more both in HIV positive and negative pregnant women. Decreasing immunoglobulin decreases degree of complement at early pregnancy and the more significant decrease of immune is mediated by the cells during pregnancy (WHO \& UNAIDS, 2004). Pregnancy in women with HIV can lead to the decrease of CD4 counts which are varied among women and will turn back to normal after delivery (Spiritia, 2009). Pregnancy management of women with HIV must be learnt in holistic view and should be perceived as a long-term treatment. Medical treatment for mothers with HIV ought to be fitted with the need of individual mother. Obstetrics management of HIV-infected mothers equals to that of HIV-negative mothers in most cases (Chou et al., 2005). Utilizing the antiretroviral drugs at the time of pregnancy to inhibit the transmission of HIV to the baby must be supported and continued. The postpartum treatment should be accompanied with the availability of contraception, supply the baby feed and appropriate follow up treatment of the baby and mother (Bobak, 2005). The transmission of HIV to the baby is very likely, about $90 \%$ babies infected with HIV was passed from their mothers during pregnancy, delivery and breastfeeding (Permenkes, 2013). WHO/ UNAIDS (2009) reported that there's significant increase in the number of children below 15 years old who are infected with HIV and about 1.2-2.9 million children. The contagion of HIV to children can happen biologically (Inherited Biological Risk) where the infection is directly passed from mother to baby conceived (Kendal, 2014). Else it can be transmitted through breastfeeding (UNICEF, 2009).

The success in medical care and treatment in preventing illnesses, and also improvement of quality of life can be measures to depict the health-related conditions of people in a country. According to WHOQOL quality of life is defined as individuals' perceptions of life roles in the cultural context and values which are believed in where the individuals live and their relations to the goal, hope and standards agreed upon by the people. This definition also considers social context and environment in measuring the quality of life besides physical 
and psychological well-being. Someone's quality of life can be measured, according to Skevington, Lofty, and O'Connell (2004) cited in Sekarwiri (2008) who suggests that measuring quality of life can be done in two ways namely measuring the overall quality of life (quality of life is seen as individual's overall evaluation of himself/herself) or only measuring certain domains/ dimensions (quality of life is measured through certain domains of somebody) (Skevington, Lotfy, and O'Connell, 2004). Based on the concept developed by WHOQOL-BREF, the quality of life can be measured by aspects of physical health, psychological well-being, social relations and environment as in Power cited in Lopez and Snyder, 2004 (Noftri, 2009).

\section{RESEARCH DESIGN}

This study is a descriptive research by using comparative methodology which aims to compare quality of life HIV-positive pregnant women to that of HIV-negative pregnant women, in dimensions of physical state, psychological well-being, social relations and environmental relations. The population is all pregnant women recruited in Medan both HIV-positive and HIV-negative. Samples were 64 pregnant women, consisting of 32 HIVpositive pregnant women and the others 32 HIV-negative pregnant women.

The technique to collect samples of HIVinfected pregnant women was total sampling. The research was conducted for three months, from October to December 2015. The location was in Medan and the surrounding.

Prior to data collecting, researcher first sat research ethical clearance test in ethical research committee at Nursing Department of North Sumatera University (USU). Instruments of the research were questionnaires of two categories. The first category is of demographic data and the second category is of quality of life of pregnant women.

Instruments were in the form of questionnaires, namely questions about quality of life regarding pregnancy and referring to questionnaires developed by WHO named WHOQOL-BREF.

The data analysis was univariate analysis on the demographic data and quality of life data. The statistical analysis of data was by comparative design using statistical independent $t$-test to derive the difference between the quality of life of HIV-infected pregnant women and that of HIV-negative pregnant women.

The result of the study: based on characteristics of respondents' data, was that HIV-infected pregnant women and HIVnegative pregnant women were at high reproductive risk of age by $50 \%$. The number of majority of babies of first pregnancy accounts 39\%. The age of pregnancy of the pregnant women was majority on the second trimester about 39\%. In general, most pregnant women were Moslems. The level of education was low levels about 63\% graduated from Junior High and Senior High schools, from Elementary schools about 13\%. The job was entrepreneur about $50 \%$. Family's monthly income was ranked low 66\% only about 700,000 rupiahs to $2,000,000$ rupiahs. Respondents' data are explained in the following tables: 
Table 1 Frequency Distribution of HIVpositive Pregnant Women and HIVnegative Pregnant Women Based on Demographic Characteristics in the City of Medan ( $\mathrm{N}=64)$

\begin{tabular}{|c|c|c|c|}
\hline No. & Characteristics & Frequency (n) & $\begin{array}{c}\text { Percentage } \\
(\%)\end{array}$ \\
\hline 1. & $\begin{array}{l}\text { Age } \\
\text { a.High reproductive risk of } \\
\text { age } \\
-<20 \text { year } \\
->35 \text { year } \\
\text { b. No High reproductive } \\
\text { risk age( } 20-35 \text { year) }\end{array}$ & 46 & 71,9 \\
\hline . & $\begin{array}{l}\text { Paritas/number of children } \\
\text { a. } \quad \text { Primigravida } \\
\text { b. } 2-3 \text { person } \\
\text { c. } \quad>3 \text { person }\end{array}$ & $\begin{array}{r}32 \\
25 \\
7\end{array}$ & $\begin{array}{r}50 \\
10,9 \\
39 \\
\end{array}$ \\
\hline 3. & $\begin{array}{l}\text { Gestation } \\
\text { a. Trimester I } \\
\text { b. Trimester II } \\
\text { Trimester III }\end{array}$ & $\begin{array}{r}25 \\
28 \\
11\end{array}$ & $17,2^{39} \begin{array}{r}43,8 \\
\end{array}$ \\
\hline 4. & $\begin{array}{l}\text { Religion } \\
\text { a.Islam/moeslim } \\
\text { b. Kristen } \\
\text { c. Budha }\end{array}$ & $\begin{array}{l}29 \\
26\end{array}$ & $\begin{array}{c}45,3 \\
40,6 \\
14,1\end{array}$ \\
\hline 5. & $\begin{array}{l}\text { Education } \\
\text { a.Elementary school } \\
\text { b.Junior high school } \\
\text { c.Senior high shool } \\
\text { d. Undergoadrate }\end{array}$ & $\begin{array}{c}8 \\
30 \\
20\end{array}$ & $\begin{array}{r}12,5 \\
46,9 \\
31,3 \\
9,4\end{array}$ \\
\hline 6. & $\begin{array}{l}\text { Working } \\
\text { a. Parmer } \\
\text { b. Enterpreneur } \\
\text { c. Goverment } \\
\text { d. Housewife } \\
\end{array}$ & $\begin{array}{l}10 \\
30 \\
10\end{array}$ & $\begin{array}{c}15,6 \\
46,9 \\
15,6 \\
21,9\end{array}$ \\
\hline 7. & $\begin{array}{l}\text { Income } \\
\text { a. }<\operatorname{Rp} 700.000,00 \\
\text { b. Rp } 700.000,00-R p \\
2.000 .000,00 \\
\text { c. }>\operatorname{Rp} 2.000 .000,00\end{array}$ & $\begin{array}{l}10 \\
30 \\
24\end{array}$ & $\begin{array}{r}15,6 \\
46,9 \\
37,5\end{array}$ \\
\hline & Total & 64 & 100 \\
\hline
\end{tabular}

\section{Quality of Life of HIV-Infected Pregnant Women}

The quality of life of pregnant women is showed in terms of all the dimensions in general.
Table 2 Frequency Distribution of Quality of Life of HIV-Infected Pregnant Women in Terms of Dimensions ( $\mathrm{N}=32)$

\begin{tabular}{|c|c|c|c|c|c|c|}
\hline \multirow[t]{3}{*}{ Dimensions } & \multicolumn{6}{|c|}{ Quality of Life } \\
\hline & \multicolumn{2}{|c|}{ High } & \multicolumn{2}{|c|}{ Moderate } & \multicolumn{2}{|c|}{ Poor } \\
\hline & (n) & $\%$ & (n) & $\%$ & (n & $\%$ \\
\hline Physical & 5 & $\begin{array}{l}15 . \\
6\end{array}$ & 26 & 81.2 & 1 & 15.6 \\
\hline $\begin{array}{l}\text { Psychologica } \\
1\end{array}$ & 4 & $\begin{array}{l}12 . \\
5\end{array}$ & 25 & 78.1 & 3 & 9.4 \\
\hline Social & 0 & 0 & 28 & 87.5 & 4 & 12.5 \\
\hline $\begin{array}{l}\text { Environment } \\
\text { al }\end{array}$ & 4 & $\begin{array}{l}12 . \\
5\end{array}$ & 25 & 78.1 & 3 & 9.4 \\
\hline
\end{tabular}

In view of the above table 5.2 , it shows that the quality of life of HIV-infected pregnant women on the dimension of physical health in general is categorized moderate quality of about $81.2 \%$, on the dimension of psychological health it is categorized moderate of about $78.1 \%$, on the dimension of social relation it is categorized moderate of about $87.5 \%$ and poor of about $12.5 \%$. Meanwhile in general the quality of life of HIVinfected pregnant women on the dimension of environmental relations is ranked moderate which amounts about $78.3 \%$. 
Table 3

Frequency Distribution of Quality of Life of HIV-Negative Pregnant Women on Each Dimensions ( $\mathrm{N}=32)$

\begin{tabular}{|c|c|c|c|c|c|c|}
\hline \multirow[t]{3}{*}{ Dimensions } & \multicolumn{6}{|c|}{ Quality of Life } \\
\hline & \multicolumn{2}{|c|}{ High } & \multicolumn{2}{|c|}{ Moderate } & \multicolumn{2}{|c|}{ Poor } \\
\hline & (n) & $\%$ & (n) & $\%$ & (n) & $\%$ \\
\hline Physical & 11 & 34.4 & 21 & 65.6 & 0 & 0 \\
\hline Psychological & 15 & 46.9 & 17 & 53.1 & 0 & 0 \\
\hline Social & 10 & 31.2 & 22 & 68.8 & 0 & 0 \\
\hline Environmental & 5 & 15.6 & 27 & 84.4 & 0 & 0 \\
\hline
\end{tabular}

Table 4

Frequency Distribution of Quality of Life of Both HIV-Positive Pregnant Women and HIV-Negative Pregnant Women (N=32)

\begin{tabular}{|l|l|l|l|l|l|l|}
\hline \multirow{2}{*}{$\begin{array}{l}\text { Pregnant } \\
\text { Women }\end{array}$} & \multicolumn{9}{|l|}{ Quality of Life } \\
\cline { 2 - 7 } & High & \multicolumn{2}{l|}{ Moderate } & \multicolumn{2}{l|}{ Poor } \\
\cline { 2 - 7 } & (n) & $\%$ & (n) & $\%$ & (n) & $\%$ \\
\hline $\begin{array}{l}\text { HIV- } \\
\text { Positive }\end{array}$ & 1 & 3.1 & 28 & 87.5 & 3 & 9.3 \\
\hline $\begin{array}{l}\text { HIV- } \\
\text { Negative }\end{array}$ & 12 & 37.5 & 20 & 62.5 & 0 & 0 \\
\hline
\end{tabular}

Table 5

Result of Independent T-Test on Quality of Life of HIV-Infected Pregnant Women and HIV-Negative Pregnant Women in Medan $(\mathrm{N}=64)$

\begin{tabular}{|l|l|l|l|}
\hline $\begin{array}{l}\text { Pregnant } \\
\text { Women }\end{array}$ & Mean & T & p-Value \\
\cline { 1 - 2 } $\begin{array}{l}\text { HIV-AIDS- } \\
\text { Positive }\end{array}$ & 18.375 & 0.011 & 0.000 \\
\cline { 1 - 2 } $\begin{array}{l}\text { HIV-AIDS- } \\
\text { Negative }\end{array}$ & 18.375 & & \\
\hline
\end{tabular}

The result of independent $t$-test shows that the qualities of life of both HIV-AIDSinfected pregnant women and HIV-AIDSnegative pregnant women are significantly different by $\mathrm{p}<0.011$.

\section{DISCUSSION}

That there is a significant difference between those two qualities of life is due to some causes like different conditions of pregnancies namely HIV-AIDS infections suffered by a group of pregnant women. HIVAIDS-infected pregnant women together with their family members face some problems associated with reproductive health which then needs acquisition and adaptation to changes appearing in them, family members and even in social perceptions which eventually affect the quality of life of those HIV-AIDS-infected pregnant women. An illness or a certain condition that someone has can cause changes in their system and function of their body which then affect their self-concept of many aspects like self-reflection, self-ideal, roles, and also prestige (Bobak, 2005). HIVAIDS-infected pregnant women will undergo dependence on others to fulfil their basic needs and health due to the decrease in their bodily functions and their lowering energy and this fact makes those women feel incomplete of being mothers thus lose their self-prestige. If these changes are not integrated with the self-concept, the quality of life of the patients will fall lower drastically (Indrayani, 2007). Quality of life of HIV-AIDSinfected pregnant women is related to the existence of changes in the reproductive processes both physically and psychologically. During pregnancy, women experience emotional changes which can lead to stress (Matteson P.S., 2001). 


\section{FINDINGS}

Physical health dimension demonstrates daily activities, dependence on drugs and on medical care, energy and fatigue, mobility, pain and discomfort, sleep and rest, and work capacity. Daily activities explain the difficulty and ease that someone faces while he is working on daily activities. Dependence on drugs and medical care/ support explains how much dependence which a person weighs to consume drugs and to ask for other medical treatments while doing those daily activities. Energy and fatigue indicate the degree of sustainability that someone has while doing those activities. Mobility indicates the degree of move that someone can do whether it is slow or fast. Sleep and rest depict the quality of sleep and rest that someone has. Work capacity explains capacity that someone has to work (Power in Lopez and Snyder, 2004).

Dimension of psychological well-being consists of body image and appearance, negative emotions, positive emotions, selfesteem and thought, learning, memory, and concentration. Body image and appearance depicts that how an individual perceives his bodily state and how he looks. Negative feelings shows that there exist unhappy feelings somebody has. Positive emotions show happy and satisfying feelings. Selfesteem explains how an individual judges and reflects himself. Thinking, learning, memory and motivation show the cognitive state of an individual which enable him to concentrate, learn, and run other cognitive activities (Power in Lopez and Snyder, 2004).

Social relation dimension consists of personal relations, social support, and sexual activities. Personal relations show relationships of an individual with others. Social support shows that there is support given to an individual by surrounding environment. Sexual activities explain sexual intercourses that an individual has (Power in Lopez and Snyder, 2004). Other than anxiety of contagion of the infection to the baby, HIVAIDS-infected pregnant women have possibility to acquire many complications to the baby and the mother themselves. Among the complications are ruptured perineum, defect baby birth, low birth weight, premature baby, and possible transmission of HIV to baby (Reeder et al., 2013).

This fact causes psychological changes like ambivalence, doubt about her pregnancy, depression, excessive worry about the baby born, and even postpartum blues after delivery. According to a research conducted by Kotze in South Africa, HIV-infected pregnant women suffered from increasing depression and anxiety of societal stigma. In term of social health, the HIV-AIDS patients face various social problems such as stigmatization, discrimination, environmental and social isolation. These social conditions affect the psychological state of the pregnant women.

International Centre for Research on Women (2003) suggests that there are many forms of stigma, among them are nicknaming/ designating, pointing, scapegoating, quipping, laughing, labelling, blaming, shaming, judging, slandering, suspecting, ignoring, rejecting, isolating, not sharing things with people with HIV-AIDS, avoiding, staying away, disturbing, physically abusing, and torturing. People who suffer from any of these forms of stigma and discrimination are reported to have been negatively affected, including the loss of income, increasing cost of health care and treatment, isolation from society and inability to take part as a member of productive societies and all because of HIV status. 
Environment dimension consists of financial sources, freedom, physical safety and security, health care and social care, home surrounding, opportunity to get new information and skill, participation and opportunity to go on vacation, physical environment, and transportation. Financial sources explain the financial situation of an individual. Freedom, physical safety and security are the degrees of security someone can perceive that affect his freedom.

Demographic and social factors in general are related to quality of life of someone, and pregnant women include. Factors that affect the quality of life are gender, education, profession/ job, age, income, and marriage status (Noftri, 2009). This opinion is in line with the theory suggesting that factors affecting the psychosocial adaptations are social economy, social culture, education, profession/ job, belief/ religion, environment and knowledge (Kasdu, 2002). Based on the result of research of respondents' characteristic data, generally the pregnant women were categorized at high reproductive risk of age about 50\%. The number of majority of babies of first pregnancy was about $39 \%$. The age of majority of the pregnancy was on the second trimester about $39 \%$. In general, most pregnant women were Moslems about 53\%. The level of education was low levels; about $63 \%$ graduated from Junior High and Senior High schools, 13\% from Elementary schools. Their job was entrepreneur about 50\%. Family's monthly income was ranked low $66 \%$ only amounting 700,000 rupiahs to 2,000,000 rupiahs. Baxter, et al. (1998) and Dalkey (2002) in (Nofitri, 2009) found that demographic factors affected the quality of life perceived subjectively.
According to characteristic data of women, in terms of education their education level was low so that their probability of improving their knowledge of health, pregnancy specifically, and HIV-AIDS, was small. The conditions of those women are parallel with opinion of Sarwono (2002) who suggests that information on someone's education and knowledge and on facts of what's happening with his environmental surrounding will be gained even if the information is hard to find. Moons, et al. (2004) and Baxter (1998) in (Nofitri, 2009) also implies that the level of education is one of factors that can affect the quality of life. Research done by Wahl, et al. (2004) in (Nofitri, 2009) reported that quality of life will increase along with the high level of education that someone has. Moons, et al. (2004) in (Nofitri, 2009) suggests that there exists difference of quality of life among people who are students, people who work, people who do not work, and people who cannot work (or who have certain defects / disabilities).

HIV-AIDS-infected pregnant women are at high risk of reproductive processes and have effects on pregnancy or complications. Therefore it is very vital to do the right conduct in treating them, for example antenatal screening, drugs therapy, antenatal treatment, delivery treatment and postpartum treatment which copes universal precaution monitoring, perineum treatment, lochea, contraception usage, bleeding treatment, wound treatment, and other related infectious risks on HIV-AIDS-positive pregnant women (Helen, 2001). Quality of life of HIV-AIDSnegative pregnant women in general is better than that of HIV-AIDS-positive pregnant women. This assumption is true to the fact that HIV-AIDS-infected pregnant women psychologically experience more changes in adaptive processes and pregnancy problems 
which make the women more isolated and prevent them from interacting with their social societies and thus diminish their quality of life. These phenomena tell that the social support especially from family members can help someone to attain comfort and security, more attention, and more respect so that the individual is eased to adapt to new entities and to face other problems and even to accept himself (Kuntjoro, 2002). Baltimor (2004) suggests that social support can help a woman understand and face life changes that have frequently occurred. Sekarwiri (2008) demonstrates that positive social and environmental support can reduce degree of stress and eventually enable them to cope with the stress, and improve the quality of life finally.

\section{CONCLUSION}

In line with the prior descriptions above, the conclusion is that:

Based on the independent t-test, there is a difference between quality of life of HIV-AIDSinfected pregnant women and that of HIVAIDS-negative pregnant women by $p$ Value $=0.000$.

\section{SUGGESTION}

More health counseling and socialization are needed especially on physical and psychological adaptation of HIV-AIDSinfected pregnant women to new changes in those aspects of life. Family members and society are advised to actively increase and play more roles in health services and treatment to lower possibility of disability of women with their conditions, so that they can live well with their pregnancy and improve the quality of life finally.

\section{REFERENCES}

Bobak, I. M., Lowdermilk, D. L., \& Jensen, M. D. (2005). Maternity nursing. $4^{\text {th }}$ ed. California: The CV.Mosby.

Chang, Viktor, T \& Weissman, D.E. (2001).Fast Fact and Concept \#52: Quality of Life. dibuka pada website http://www.my whatever.com pada tanggal 25 april 2013.

Departemen Kesehatan RI. (2013). Riset Kesehatan dasar (Riskesdas) 2007: laporannasional 2013. Jakarta: Badan Penelitian dan Pengembangan Kesehatan Depkes RI.

Gorrie, T. M., McKinney, E. S., \& Murray, S. S. (1998). Foundation of maternal newborn nursing, $2^{\text {nd }}$ ed. California : Saunders.

Hamilton (1995) Dasar-dasar Keperawatan Maternitas, alih bahasa Ni Luh Gede Yasmin Asih, EGC, Jakarta. Notoadmodjo, S. (2003). Pendidikan dan Prilaku Kesehatan. Jakarta: Rineka Cipta.

Hinks, A. (2010). When motherhood beckons : an exploration of the transition to motherhood for HIV positive women. The Jurnal Of Bone and Joint Surgery (Br) 0301-620X/02/612641.

Helen. F. (2001) Perawatan Maternitas, alih bahasa Yasmin Asih. EGC, Jakarta.

Ibrahim, Z. (2002). Psikologi Wanita (terjemahan). Bandung. Pustaka Hidayah

Kendall, T., \& I. Danel (2014). Research and Evaluation Agenda for HIV and Maternal Health in sub-Saharan Africa: Women and Health Initiative Working Paper No.1. Women and Health Initiative, Harvard School of Public Health: Boston, MA. http://www.mhtf.org. Diperoleh tanggal 27 Juni 2014. 
Khamsawarde, N. (2010). Comparison of selfcare behavior between HIV/AIDS infected and non-infected mothers. www.unaids.org. Diperoleh tanggal 29 November 2014.

Matteson, P. S. (2001). Woman's health during the childbearing years: A community baced approach. St. Louis : Mosby Inc.

Nofitri.(2009). Kualitas Hidup Penduduk Dewasa di Jakarta. Dibuka pada website: http://www.lontar.ui.ac.id dibuka tanggal 22 juni 2013.

O'Connel.R (2004). Issue in the Meansurement of health Quality of life. Center for health program Evaluasi dibuka pada website http://www.rodoconnorassooc.com/iss ue in meansurment of qua.htmdibuka pada tanggal 22 juni 2013.

Pillitteri, A. (2003). Maternal \& child health nursing : Care for chilberaing \& childrearing family. (4th ed.), Philadelphia: Lippincott Williams \& Wilkins.

Reeder, S.J., Martin, L.L. \& Koniak, D.(1997). Maternity nursing, family, newborn \& women's health.. (8nd ed.) Philadelphia: Lippncott.

Surlis, S., \& Hyde, A. (2001) HIV-positive patients experiences of stigma during hospitalization. Journal of the Association of Nurses in AIDS Care, 12(6):45-54 http://hdl.handle.net. Doi 10.1016/S1055-3290(06)60185-4.

Sekarwiri, E. (2008). Hubungan Antara Kualitas Hidup Dengan Sense of Community. Dibuka pada website: http://www.google.co.id. Pada tanggal 25 Agustus 2013.

Steward, M.J. (1993). Integrating social support in nursing, New Delhi : Sage

Streubert, H.J., \& Carpenter, D.R. (1995). Qualitative research in nursing : advancing the humanistic imperative. Philadelphia. Lippincott Company.

Swasono, Meutia F.(1998). Kehamilan Kelahiran, Perawatan Ibu Dan Bayi Dalam Konteks Budaya. Jakarta. UI press.

WHOQOL Group.(1998). Development of the world health organization WHOQOLBREF Quality of life Assesment. Psychcological Medicine. Dibuka pada website http://www.who.int/mentalhealth/evid ence/whoqolpdf pada tanggal $25 \mathrm{Mei}$ 2013.

WHO. (2013). Women's experiences in services for preventing the mother-tochild transmission of HIV: a literature review. 